\title{
REACTIONS OF SMALL TO MEDIUM ENTERPRISES IN MASVINGO, ZIMBABWE TO COVID 19: IMPLICATIONS ON PRODUCTIVITY
}

\author{
Takupiwa Nyanga \\ Julius Nyerere School of Social Sciences, Great Zimbabwe University, Masvingo, Zimbabwe \\ takupiwa@gmail.com \\ Herbert Zirima \\ Julius Nyerere School of Social Sciences, Great Zimbabwe University, Masvingo, Zimbabwe \\ hzirima@gzu.ac.zw
}

\begin{abstract}
The COVID 19 pandemic has had a significant impact on livelihoods; the virus has affected not only the health sector but the work life of people as the government instituted measures to contain the spread of the virus. This study sought to explore how SMEs in Masvingo, Zimbabwe were affected by a government declared lockdown. In particular, the study sought to establish how the SMEs responded to the lockdown, the strategies that they instituted and the implications of the lockdown on the productivity of the SMEs. A qualitative approach was adopted specifically adopting the descriptive case study approach as a research methodology. Ten participants who participated in this study were conveniently selected from 7 purposively selected SMEs in Masvingo town. Indepth interviews were used for data collection. Results indicated that SMEs were negatively affected by the lockdown. Most of them stopped operations and had to lay off some of their employees. Production in most cases was halted and this entailed that the future after the lockdown was bleak for them. The SMEs appealed for government support to enable them to resuscitate after the lockdown.
\end{abstract}

Keywords: COVID 19, employee, employer, lockdown, manufacturing small to medium enterprises, productivity.

\section{INTRODUCTION}

Coronavirus disease (COVID-19), a disease that emerged in the city of Wuhan, China, in December 2019 has spread to more than 150 other countries and has since caused a large-scale epidemic (Wu et al., 2020). The outbreak was declared a Public Health Emergency of International Concern on 30 January 2020 (WHO, 2020). The outbreak has already transformed into an economic and labor market shock, affecting not only supply (production of goods and services) but also demand (consumption and 
investment) (ILO, 2020). The pandemic has undoubtedly affected the work environment and as such organizations and how they operate on a day to day basis.

At a global level, WHO has been giving guidelines on ways to prevent the spread of COVID 19 at the workplace. Such guidelines include precautions that relate to managing COVID 19 risks when organizing meetings and events and getting the workplace ready in case COVID 19 arrives in the community (WHO, 2020). Such guidelines have the net effect of either reducing production or stopping production completely as employees have to either completely stay at home or in some instances have a skeletal staff at the workplace. According to OECD Economic Outlook Interim report of March 2020, projections for annual global GDP growth for 2020 have dropped by half a percentage point to $2.4 \%$ due to the coronavirus outbreak. However, a longer lasting and more intensive coronavirus outbreak could slow global growth to $1.5 \%$ (OECD, 2020). COVID 19 poses a significant threat to the millions of small and medium based enterprises (SMEs) across the world, more so in the most vulnerable countries. SMEs account for more than $90 \%$ of employment in developing countries and yet they facing export restrictions, closed borders, decreasing demand and rapid slowdown in global supply chains (ITC, 2020). Disruptions to production, initially in Asia, have now spread to supply chains across the world. All businesses, regardless of size, are facing serious challenges, especially those in the aviation, tourism and hospitality industries, with a real threat of significant declines in revenue, insolvencies and job losses in specific sectors. Sustaining business operations will be particularly difficult for Small and Medium Enterprises (ILO, 2020).

Based on a survey of SMEs in February 2020, reports on China showed that a third of SMEs only had enough cash to cover fixed expenses for a month, with another third running out within two months, putting millions of Chinese SMEs at risk. Reporting on 14 March 2020, suggests $60 \%$ of Chinese SMEs are back in business, but now face further challenges due to reduced demand from other markets (OECD, 2020). That impact was later felt in European countries as the virus spread to their territory. A survey of SMEs in Poland, published on 10 March 2020, showed that 30\% of SMEs feared a decrease in sales and worker availability in the next three months.13 Over one-third experienced increased costs and reduced sales, with $27.5 \%$ of respondents already encountering cash flow problems (OECD, 2020). In the African region, the COVID 19 outbreak has rapidly evolved and spread to almost all the parts of the continent. By the $25^{\text {th }}$ of March 2020, a cumulative total of 1716 cases had been reported in the African continent (WHO, 2020). Government and organizations in Africa have largely responded to the pandemic by adopting a 'copy and paste' approach of the strategies used in China and the Western world. Some African countries, such as Rwanda and South Africa have declared complete lockdowns as a way of containing the spread of COVID 19. Such lockdowns have an adverse effect on SME productivity. It is because of that real and anticipated drop in productivity that South Africa has availed a 
Nyanga, T., Zirima, H.

REACTIONS OF SMALL TO MEDIUM ENTERPRISES IN MASVINGO, ZIMBABWE TO COVID 19: IMPLICATIONS ON PRODUCTIVITY

R1 billion funding from the Rupert family and Remgro limited (CNBC Africa, 2020). While there are no available statistics to ascertain the exact impact of COVID 19 on African SMEs, the strain that they encounter cannot be doubted. In Ethiopia, SMEs in the textile industry are retooling their production lines to produce face masks for the health sector (ITC, 2020).

Zimbabwe declared a lockdown starting on the $30^{\text {th }}$ of March 2020 as a measure to prevent the spread of COVID 19. The lockdown meant that organizations offering non-essential services were expected to close shop. This undoubtedly impacted a lot of SMEs as only the health sector and those industries supporting the health sector were allowed to remain open. SMEs employ the majority of people in Zimbabwe and they form the backbone of the economy especially in small towns such as Masvingo (Nyanga et al., 2013). This study seeks to explore how SMEs have responded to the lockdown, the strategies that they have adopted as well as their interpretation of how the lockdown has and will affected their productivity.

\section{RESEARCH QUESTIONS}

\section{Main Research Question}

How has COVID 19 affected the productivity of SMEs in Masvingo, Zimbabwe?

\section{Sub Questions}

1. In what ways have SMEs been affected by the COVID 19 lockdown?

2. How have SMEs in Masvingo responded to the COVID 19 lockdown?

3. How can productivity be improved for the SME sector?

\section{METHODOLOGY}

A qualitative research approach was employed in carrying out the study specifically making use of the descriptive case study design. The population of the study comprised all SMEs in Masvingo town. The sample of study comprised 7 SMEs purposively selected from Masvingo city, Zimbabwe. Masvingo city is home to several SMEs hence SMEs have become the major employers of various categories of people. 10 participants from the 7 SMEs were conveniently selected to participate in the study. The researchers interviewed those employees whom they found at organizations premises during the time of the visit. The researchers sought and were granted permission by chief executive officers and in some cases by human resource managers to carry out the study at their organizations. Data was collected through in-depth interviews collected over a three-day period. Data was analyzed using thematic data 
analysis method. Themes and sub-themes were drawn as the researchers went through the interview notes and also listening to audio recorded interview reports.

\section{RESULTS AND DISCUSSIONS}

\section{Effects of COVID 19 on SMEs}

This study revealed that SMEs were affected by the corona virus pandemic in various ways. When the government and other international health promoting institutions such as WHO declared COVID 19 a disaster and a pandemic, almost all the businesses began to feel the consequences of disease, but the hardest hit were small businesses. Almost all business activities came to a halt because COVID 19 restricted the movement of people locally and internationally. The world has become a global village hence SMEs found it difficult to continue operating their businesses since they relied on buying their goods for sale from other countries such as China, Tanzania, South Africa and Dubai. Since the beginning of January 2020 SMEs faced huge challenges of re-stocking their businesses. The operation challenges of SMEs were worsened by governments of different countries' decisions to lockdown their countries as way of reducing the spread of the disease. Lockdown has been viewed throughout the world as the best strategy of managing the spread of COVID -19 hence the decision by Zimbabwean government is applauded. In an attempt to follow the government directive, the productivity of the SMEs was significantly lowered because virtually all SMEs in Masvingo closed shop as a result of the COVID lockdown. The SMEs reported that since most of their activities are in the non-essential services category, they had to close shop as a way of preventing the spread of the virus. Participant 1 indicated that "we had to close all our furniture workshops as these are not regarded as essential services". Participants 6 highlighted that "we closed our two workshops because we do not even expect to receive any customers since movement is restricted". Participant 3 indicated that "I have to close my market stalls because of the government lockdown, now I am afraid all my fresh produce will get rotten as I do not anticipate many customers due to the instruction that people should stay at home." Participant 9 expressed that "in response to the lockdown, we had to lay off our attaches and our temporary workers, we cannot afford to sustain them when we are not producing anything." These sentiments indicate that production was seriously lowered by the closing down of business in response to the COVID 19 breakdown. This concurs with what happened in China where decline in economic activity and constraints on people's movements impacted both manufacturing and services. The most recent data shows that the total value added of industrial enterprises in China declined by 13.5 per cent during the first two months of 2020 (Baldwin \& Di Mauro, 2020). Furthermore, SMEs were affected by COVID 19 in the sense that they were forced to lay off almost all their temporary employees because they could not 
afford to raise enough money to pay their wages. There is absolutely no guarantee that all the laid off workers would re-join the same SMEs, if they do so they may have a negative attitude towards them which in a way leave SMEs with less skilled people or lowly satisfied human capital.

\section{SMEs Interventions to minimize the spread of the virus}

The study revealed that one of the intervention strategies employed by organizations to reduce the transmission of the corona virus is through providing employees and the public with information regarding COVID-19, its causes, how it is transmitted and precautionary measures that can be taken to avoid the spread of the virus. The provision of information about the disease capacitates workers to take precautionary measures that reduce the transmission of the disease. Several organizations in Zimbabwe assist in reducing the spread of the corona virus by disseminating information about the virus by putting posters on strategic positions, SMs, social media and other platforms which can be accessed by their employees and the public in general. For example, one of the participants working for a local university indicated that his employer made and posted several posters on Covid-19 in and around Masvingo town. Participant 12 was satisfied by the efforts organizations were making to avert the spread of the disease and had this to say, "Several banks in Zimbabwe circulate messages encouraging their clients not visit banks but to use e-banking. For instance, I received the following message from ZB bank 'In light of recent developments we urge you to self-register for internet banking .... 24 hours assistance is available on the website live chat.' Steward Bank, "Avoid handling cash to stay safe from exposure to Covid-19 and dial *210\# for your banking requirements. Prevention is better than cure." Other companies used their Facebook, twitter and WhatsApp platforms to disseminate information about the virus. The messages help employees and the general public to stay safe from exposure to the corona virus. Organizations therefore support government efforts to fight the pandemic by reducing chances of people contracting the disease. Most organizations do such activities as part of their corporate responsibility. Organizations meet all the costs that are involved in the dissemination of information related to the corona virus disease to the public.

Furthermore, organizations in Zimbabwe participate in fighting the corona virus pandemic by organizing training workshops for their employees and the generality of people. Online workshops were mainly used by the majority of organizations so as reduce the spread of the virus. One of the respondents said, "Employers should capacitate employees to deal with the corona virus through training. Training is essential in that it equips employees with signs and symptoms of the disease and how it is transmitted". Employers should use their internal training arms such as the human resource management departments and line departments to plan, organize and operationalize training workshops and 
programs aimed at equipping employees with information regarding the spread of COVID-19. Furthermore, organizations can engage an outsider or training Consultancy Company to equip employees on the transmission and treatment and management of COVID 19 or the corona virus. In times of epidemics training can be used to spread information about the disease, its management and treatment. For example, the world through various health enhancing institutions such as World Health Organizations (WHO), United Nations Children Emergency Fund (UNICEF) managed the HIVIAIDS pandemic through training employees and the general public about how it is spread, how it can be prevented and ways of managing it. Employers also played a key role on disseminating information about the pandemic through training and policy formulation and implementation. The lightning speed at which the corona virus pandemic is spreading is alarming hence living the responsibility to health officials to help control it will be in a way negating the fundamental role and function of the human resource management to promote good health and safety on employees. Organizations should provide as much information about the corona pandemic as possible so that people engage in life styles that reduce the spread of the virus.

The other intervention which organizations can put in place to reduce the transmission of COVID 19 is for organizations to provide financial and material resources to augment government efforts on managing the pandemic. Organizations in Zimbabwe provide financial resources to procure screening equipment and also consumables needed during prevention, screening and also curing patients. Consumables required include among others protective clothing such as gloves, masks and others needed by health practitioners. Governments of developing economies such as Zimbabwe, Malawi, Mozambique, Zambia and others usually face problems of failing to manage pandemics because of failing to raise adequate financial resources to provide consumables needed by health practitioners. For example, there was a newspaper report of Monday 23 March 2020 which purported that nurses in Zimbabwe were considering engaging in a collective job action because of the failure by their employers to provide adequate protective clothing, which consequently put them at risk of contracting the disease. Participant 9 remarked, "Most hospitals in developing countries do not have enough resources to provide health professionals with enough and modern protective clothing to protect them from contracting COVID 19." Failure by authorities to supply adequate protective clothing for health professionals directly or indirectly dealing with COVID 19 pandemic make health professionals scared and reluctant to help patients and also reduces their level of job satisfaction. Studies (Nyanga, 2018) are of the view that job satisfaction is one of the major factors that propel employee effectiveness, efficiency and commitment, lack of it results in poor performance. Nurses and doctors just like all other people need to be satisfied with their jobs if they are going to expend all their energy towards reducing the spread and treatment of COVID 19 pandemic. Furthermore, most employees' medical aid services 
in Zimbabwe have depleted because of high inflation currently bedeviling the country. Most people do not afford to buy medication to deal with the corona virus pandemic and also buy protective clothing such as sanitizers, masks and soap needed to prevent the spread of the disease. Some medical aid societies cannot afford to pay in full their clients' medical bills; hence employers need to pay off the balance so that employees remain in good health. Employers can also provide sanitary equipment to employees so that the spread of the disease is reduced. Furthermore, most organization have shifted from emphasizing on the realization of goals and focused on human capital safety. Organizations put in place measures to protect their workers by restructuring their workplaces and ensuring that employees are not overcrowded in an office and in a workshop. A lot of financial resources have been re-directed from re-capitalization of companies to fighting the corona virus pandemic. It shows that while organizations were established to make profits and increase the value of shares they are also concerned about the welfare of their employees. Reducing the number of workers in a production plant at a time or totally shutting down the plant.

Organizations have also complied with government policy to avoid ferrying workers in overcrowded company buses or any other forms of transport to and from work. The majority of middle class and lowclass workers in developing countries use public transport to and from work hence there are very high chances of an increase in the transmission of the virus from one passenger to the next mainly because of the distance between passengers in buses. Participant 10 said, "I use the Zimbabwe Passengers Company bus to and from work. There was a very high risk of the transmission of COVID 19 because the bus was always overloaded, but the situation has changed since the company has since complied with government policy of maintaining a 2 or so meter distance". Participant 7 remarked, "I am in the construction industry, our employer ferries us to and from work with his truck. The truck will be packed with workers which technically put workers at risk of contracting COVID 19. I have advised my employer to either stop using the lorry to ferry people and allow people to walk to the work station or ferry people in small groups of fives." Organizations therefore reacted differently to the call by government to put in place precautionary measures to reduce the spread of the disease. Public transport can be a vehicle of spreading COVID 19; hence employers and public transporters should ensure that their workers and the public use forms of transport that are safe or with limited chances of the spread of the corona virus. To stop or reduce the spread of the corona virus the Chinese government had to quarantine almost all the people in affected areas and also to put regulations that restricted the movement of both private and public forms of transport. While the spread of the disease is still very low in Zimbabwe and other surrounding countries in the exception of South Africa, there is need for organizations to take precautionary measures on the means of transport workers use to and from work. The ban by 
government for the public from using private transport operators and use only ZUPCO will go a long way in averting the spread of the disease. Buses can be high risk areas for transmitting COVID 19 to workers and the generality of Zimbabweans. One of the precautionary measures is to make all the passengers wash their hands using sanitizers as they board the bus. Furthermore, employers should encourage workers to avoid staying in public places such as pubs, churches, funeral services and other types of family gatherings.

The study also established that organizations that are in funds should establish onsite clinics to report and refer suspected corona infected workers to better equipped hospitals to deal with the disease. Nyanga and Sibanda (2019) observed that on-site health facilities play a major role in dealing with pandemics. It is therefore critically essential for organizations to have on site clinics or for a group of companies in the same neighborhood to put their resources together and establish a health center with well-trained health practitioners on issues to do with COVID 19. On-site resident health practitioners help to quickly detect COVID 19 infected employees and have them receive treatment before they deteriorate. The findings are consistent with preceding studies that established that the availability of accurate and robust epidemiological, clinical, and laboratory data early in an epidemic is important to guide public health decision-making. Consistent recording of epidemiological information is important to understand transmissibility, risk of geographic spread, routes of transmission, and risk factors for infection, and to provide the baseline for epidemiological modeling that can inform planning of response. It is essential to detect the corona virus patients early so that they can be assisted before the disease is transmitted to other employees. Apart from having on-site clinics employer introduced flexible work arrangements such as compressed work weeks, flextime and more importantly telecommuting. Flexible work arrangements reduce the chances of people meeting as a group since workers would go to their work stations as and when it becomes inevitable for them to work from home. Employees should be encouraged to use social media and other internet aided business programs to conduct their duties. Such an approach significantly reduces the transmission of the disease since employees will not be meeting in large numbers. Employees should be encouraged to avoid visiting banks and use e-banking system since banks are almost always crowded with clients, which makes it a high-risk corona virus transmitter. The study also revealed that a sizable number of people especial those who are selfemployed ignored the call by government and other stake holders to seriously take precautionary measures to stop the spread of the disease. Although people have adequate information about the disease, they decided to continue to do their socio-economic activities such as running their businesses and visiting beer halls as usual. One of the major excuses that was given for not adhering to ways and means of reducing the spread of the disease was the unfavorable economic environment which did not permit organizations and individuals to take a break since they needed to meet their financial obligations 


\section{REACTIONS OF SMALL TO MEDIUM ENTERPRISES IN MASVINGO, ZIMBABWE TO COVID 19: IMPLICATIONS ON PRODUCTIVITY}

by the end of month such as paying rentals, paying for services and buying food for the family. Failure by people to change their behavior in light of the COVID -19 pandemic has been and is major concern for most organizations and the government.

\section{Strategies to Maintain or Improve productivity}

The study revealed that one of the strategies employed by SMEs to maintain productivity and their cash flow levels is to depart from the conventional way of doing business and embrace the online business trading system. SMEs conduct their businesses using the online system where they buy and sell their products online, hold organizational meetings online and keep in touch with their employees and customers via the email and social media platforms such as WhatsApp. Some SMEs sell their products online and deliver them to their customers, but as they deliver the products, they should take precautionary measures that reduce the spread of the virus as outlined by WHO and the local health system. E-commerce gives SMEs an opportunity to continue running their businesses while at the same time complying with the 21-day COVID-19 lockdown directive by government. Furthermore, almost all SMEs sales are done in more stable and reliable currencies such as the US dollar, the South African rand and the Botswana pula, so that SMEs are not affected by the inflationary tendencies of the Zimbabwean currency. However, buying goods using hard cash is very risk because it can be an ease way of transmitting the corona virus so SMEs need to put measures that reduce the spread of the disease. The risk averse SMEs decided to suspend operations and stocked their goods in warehouses and would resume work as soon as the risk of contracting the coronavirus and losing their stock to the 21-day COVID 19 lockdown enforcement agents is low. Temporary and attaché workers were to be laid off so as to reduce labor costs and increase cash flows and profitability. The reduction of the workforce coupled with the reduction in other production costs such as telephone bills, water and electricity bills helped most SMEs to remain afloat. The other survival strategy which SMEs employ is complying with government directives so that they contribute to the eradication of the COVID-19 scourge and also avoid receiving heavy sanctions and penalties that can cost them a lot of money.

\section{CONCLUSION}

The impact of the COVID 19 pandemic was not only felt in the health sector but also on SME sector productivity. This study revealed that the SME sector was hard hit by the COVID 19 pandemic. The lockdown which followed as a measure to contain the spread of the virus lead to the closure of virtually all SMEs in Masvingo. That then led to a serious drop in production which meant that temporary employees and attachés had to be laid off. The net effect of COVID 19 on SMEs is that it significantly 
lowered productivity as most of them did not have the capacity and means to enable production whilst employees are at home. Most of their customers depend on physically walking in on the premises of the organization and the activities that they do usually require that they be physically present at their workshops. This then means that the directive to limit the movement of people directly affected their productivity. A sizeable number of SMEs preferred to disobey the lockdown regulation and continue with their socio-economic activities as usual since they felt that reducing operations could hinder them from meeting their financial obligations such as paying rent, service charges, food and other related costs.

\section{RECOMMENDATIONS}

This study recommends that:

- The government should explore ways of giving SMEs a rescue package to enable them to recuperate after the end of the lockdown.

- SMEs should explore creative ways of operating besides conventionally relying on their physical workshops. For example, they may explore ways of allowing their employees to work from home and adopting digital means of offering their services.

- Future studies should quantitatively measure the impact of the lockdown on the productivity of the SMEs.

\section{REFERENCES}

Baldwin, R., Di Mauro, B.W. (2020). Economics in the Time of Covid-19. CEPR

CNBC (2020). Update on Rupert family's R1bn COVID-19 fund. Retrieved April 9, 2020, from https://www.cnbcafrica.com/videos/2020/04/09/update-on-rupert-familys-r1bn-covid-19-fund/

International Labour Organisation (2020). COVID 19 and the world of work: Impact and policy responses. Retrieved April 1, 2020, from https://www.ilo.org/wcmsp5/groups/public/---dgreports/

International Trade Centre (2020). COVID 19 and Small Businesses. Retrieved March 27, 2020, from http://www.intracen.org/news/Message-from-ITC-Executive-Director-ai-on-COVID-19-and-smallbusinesses/

Nyanga, T. (2018). Examining the Usefulness of Job Satisfaction Theories in Armed Conflict Society. Amity Global Human Resource Management Review, 8(2), 40-48.

Nyanga, T., Sibanda, R. (2019). Magnet that Truss Domestic Workers and Employers in Armed Conflict Societies: A Case of Mazoe in Changara District in Mozambique, Journal of Vietnam Academy of Social Sciences, 20(4), 22-36.

Nyanga, T., Zirima, H., Mupani, H., Mashavira, N., \& Chifamba, E. (2013). Survival of the Vulnerable: Strategies Employed by Small to Medium Enterprises in Zimbabwe to Survive an Economic Crisis. Journal of Sustainable Development in Africa, 15(6), 39-71. 
Nyanga, T., Zirima, H.

REACTIONS OF SMALL TO MEDIUM ENTERPRISES IN MASVINGO, ZIMBABWE TO COVID 19: IMPLICATIONS ON PRODUCTIVITY

OECD (2020). Covid-19: SME Policy Responses. Retrieved March, 8, 2020 from https://www.oecd.org/economic-outlook/

World Health Organisation (2020). Situation reports on COVID 19 outbreak. Retrieved April 3, 2020, from https://www.who.int/docs/default-source/coronaviruse/situation-reports/20200402-sitrep-73covid-19.pdf?sfvrsn=5ae25bc7_2

Wu, J.T., Leung, K., Bushma, M., Kishore, N., Niehus, R., Pablo, P., Salazar, B., Cowling, B.J., Lipsitch, M., \& Leung, G.M. (2020). Estimating clinical severity of COVID-19 from the transmission dynamics in Wuhan, China. Nature Medicine, 1-5. https://doi.org/10.1038/s41591-020-0822-7 